\title{
PERFORMANCE OF LOW CARBON MODIFIED COMPOSITE GYPSUM BINDERS WITH INCREASED WATER RESISTANCE
}

\author{
Myroslav Sanytsky ${ }^{1,}$, Tetiana Kropyvnytska ${ }^{1}$, Hans-Bertram Fischer ${ }^{2}$, \\ Nataliia Kondratieva ${ }^{3}$
}

https://doi.org/10.23939/chcht13.04.495

\begin{abstract}
This paper presents the investigations of the environmental advantages of low carbon composite gypsum binders for building applications. The impact of ultrafine zeolite additive on the physico-mechanical properties and hydration processes of composite gypsum binders has been investigated. The modification of gypsum pastes by polycarboxylate type superplasticizer results in the radical change in the formed microstructure of composite gypsum binders. The obtained results are essential for further design and development of new types of gypsum composites with an increased water resistance.
\end{abstract}

Keywords: low carbon composite gypsum binders, multicomponent cements, natural zeolite, polycarboxylate modifier, compressive strength, water resistance.

\section{Introduction}

Sustainable efforts aimed at a substantial reduction of carbon dioxide emissions are focused at the researches in the field of cement chemistry that provide the possibility for partial or complete replacement of ordinary Portland cement by environmentally friendly binders. So, nowadays the significance of calcium sulphate plasters increases, because they belong to the most ecologically favorable binders due to their low energy demand during production. However, gypsum products have low resistance to water. The improved constructional and technical properties of gypsum products, in particular, their increased strength and water resistance, are actually provided by two ways: the formation of products with a reduced water/gypsum ratio or the introduction of Portland cement and active mineral additives to the gypsum binder [1-3].

\footnotetext{
${ }^{1}$ Lviv Polytechnic National University,12, Bandera St., 79013 Lviv, Ukraine

${ }^{2}$ Bauhaus-Universitat, FIB, WdB Betriebsleitung Coudraystraße 11, 99421 Weimar, Germany

${ }^{3}$ Ukrainian State University of Chemistry and Chemical Technology,

8, Haharin Ave., 49005 Dnipro, Ukraine

msanytsky@ukr.net

(C) Sanytsky M., Kropyvnytska T., Fischer H-B., Kondratieva N., 2019
}

One of the ways to increase gypsum products water resistance is the use of gypsum-cement-pozzolanic binders (GCPB). Such binders have the ability to hydraulic hardening. Unlike conventional ones, they allow to receive waterproof concrete and mortars [4-5]. The formation of the denser microstructure of a gypsum stone with increased strength and water resistance is largely achieved by modification with surfactants. In this case, the gypsum binder strength is increased due to the phenomenon of adsorption modification of calcium sulfate dihydrate crystals, which are formed in the early period of structuring. The strength of individual contacts between the crystals and the number of contacts per unit of the failure surface determined the mechanical properties of gypsum stone [6-8]. The combination of gypsum binder with organo-mineral modifiers, which includes Portland cement, active mineral additives and fine fillers, as well as superplasticizer, allows to obtain a new generation of GCPB - hydraulic composite gypsum binders of low water demand (CGB) [9].

The strength and water resistance of the composite gypsum binder largely depend on the fractional composition of its components [10]. Therefore, it is important to study the impact of the surface area and the granulometric composition of the composite gypsumcement-pozzolanic binders on the density of their packaging. The composition design of composite gypsum binders provides the optimal combination of gypsum binder, Portland cement clinker, active mineral additions and fillers to obtain composites with necessary physical and mechanical characteristics. In this process, the formation of composite materials should be considered in order of scale levels reduction from macro- to nanostructural. The positive effect of monodispersed additives should be noted on the structure and physicomechanical characteristics of composite materials [11].

The use of composite cements with a high content of active mineral additives of hydraulic and pozzolanic action provides significant reserves for reducing energy intensity and the carbon footprint of such binders. The high activity of ultrafine natural zeolite tuffs in the binding of lime and 
gypsum to the hydrated phases opens up the possibility of their effective use in composite cements [12-15]. Therefore the hydraulic properties of gypsum binders at the present level may be also provided by physico-chemical modification of their properties by means of organomineral additives of polyfunctional action, which have several positive effects due to a synergistic combination. Moreover, the combination of gypsum binder and multimodal composite cements with natural components such as zeolite tuff, limestone, etc., is relevant for the further development of low-energy building composites based on modified composite gypsum binders.

The aim of this paper is to increase the water resistance of gypsum binders by optimization of their fractional composition, ratio of Portland cement and natural pozzolana (zeolite tuff), as well as by using superplasticizers of the new generation. Creation of modified composite zeolite-containing gypsum binders, which improve the building properties of articles, allow significantly to expand application area, and minimize the energy consumption and carbon footprint of products on their basis.

\section{Experimental}

\subsection{Materials and Methods}

The materials used in the experiments were taken at PJSC "Ivano-Frankivsk Cement" (Ukraine): gypsum building binder of G- 6 brand based on calcium sulphate $\beta$ hemihydrate $\left(\mathrm{CaSO}_{4} \cdot 0.5 \mathrm{H}_{2} \mathrm{O}\right)$, Portland cements CEM I 42.5, CEM II/A-P 32.5, CEM II/B-M(S-P-L) 32.5 $\mathrm{R}$ on the basis of clinker of normalized mineralogical composition (wt \%: $\mathrm{C}_{3} \mathrm{~S}-62.42 ; \mathrm{C}_{2} \mathrm{~S}-13.62 ; \mathrm{C}_{3} \mathrm{~A}-$ 7.06; $\left.\mathrm{C}_{4} \mathrm{AF}-12.32\right)$, as well as a special masonry cement MC 22.5X. Granulated blast furnace slag (S), natural pozzolana-zeolitic tuff $(\mathrm{P})$ and limestone powder $(\mathrm{L})$ were chosen in the experiments as a representative of the family of Portland cements composite.
Gypsum paste of normal consistency (slump-flow test by Suttard cylinder is $180 \mathrm{~mm}$ ) and standard specimens were tested. Immediately after mixing with water, the samples were casted into the form of size $40 \times 40 \times 160 \mathrm{~mm}$. After $2 \mathrm{~h}$, the samples were unmolded and tested for compressive strength. The specific surface area (SSA) of gypsum binder is $480 \mathrm{~m}^{2} / \mathrm{kg}$, a grinding fineness is $4.8 \%$. To provide the standard consistency of gypsum paste, the water demand is $61 \%$, the initial and finish setting time of the paste is 10 and $18 \mathrm{~min}$, respectively. In this case, the compressive strength after $2 \mathrm{~h}$ is $6.54 \mathrm{MPa}$, the softening coefficient (which characterizes the water resistance of the material) $K_{s}=0.48$.

Values of compressive and flexural strengths of the cements under study were determined on mortar prisms $(40 \times 40 \times 160 \mathrm{~mm})$ as prescribed in EN 196-1. Consistency of the fresh mortars (expressed by a flow value) was determined as prescribed in EN 1015-3. The superplasticizer based on the polycarboxylate ether (PCE) MasterGlenium ACE 430 (BASF) was used to modify the properties of composite gypsum binders.

The chemical compositions of gypsum binder, Portland cements and zeolite tuff were determined by X-ray spectrometer ARL 9800 XP. Fractional composition and grinding fineness of gypsum binder, cement and mineral additives were studied using a sieve analysis and determination of specific surface on Blaine apparatus; the particle size distribution (PSD) was determined using a Mastersizer 3000 laser analyzer. The physical and mechanical properties of gypsum binders and cements were determined in accordance with current standards and generally accepted techniques. The reflection coefficient of cements was determined using a photoelectric gloss meter FB-2. The phase composition of the starting materials and hydration products of composite gypsum binders was studied using a set of modern physico-chemical methods of analysis: XRD, DTA, SEM.

Chemical compositions of gypsum, natural zeolite and cements CEM I 42.5, CEM II/A-P 32.5, CEM II/ B-M 32.5, MC 22.5X are given in Table 1.

Table 1

Chemical composition of materials

\begin{tabular}{|l|c|c|c|c|c|c|c|c|c|}
\hline \multicolumn{1}{|c|}{ Material } & $\mathrm{CaO}$ & $\mathrm{SiO}_{2}$ & $\mathrm{Al}_{2} \mathrm{O}_{3}$ & $\mathrm{Fe}_{2} \mathrm{O}_{3}$ & $\mathrm{MgO}$ & $\mathrm{Na}_{2} \mathrm{O}$ & $\mathrm{K}_{2} \mathrm{O}$ & $\mathrm{SO}_{3}$ & $\mathrm{LOE}$ \\
\hline Gypsum binder & 32.5 & - & - & - & - & - & - & 46.6 & 20.9 \\
\hline Zeolite tuff & 1.54 & 72.85 & 11.48 & 2.58 & 0.51 & 1.25 & 2.44 & 0.03 & 7.33 \\
\hline CEM I 42.5 & 64.25 & 20.31 & 5.25 & 3.71 & 0.87 & 0.19 & 1.03 & 3.54 & 0.85 \\
\hline CEM II/A-P 32.5 & 56.90 & 26.02 & 6.37 & 3.37 & 1.60 & 0.39 & 0.89 & 2.48 & 1.98 \\
\hline CEM II/B-M 32.5 & 54.38 & 29.60 & 7.21 & 3.23 & 1.76 & 0.52 & 0.96 & 2.01 & 0.33 \\
\hline MC 22.5X & 50.39 & 32.62 & 6.49 & 2.71 & 1.46 & 0.82 & 1.09 & 0.90 & 3.52 \\
\hline
\end{tabular}


Zeolite tuff of the Sokirnitsky deposit (content of active $\mathrm{SiO}_{2}$ is $70-75 \%$ ), was used as an active mineral additive for composite cements. Zeolite tuff contains from 60 to $80 \mathrm{wt} \%$ of clinoptilolite $\left(\mathrm{Na}_{2}, \mathrm{~K}_{2}\right) \mathrm{O} \cdot \mathrm{Al}_{2} \mathrm{O}_{3} \cdot 10 \mathrm{SiO}_{2} \cdot 8 \mathrm{H}_{2} \mathrm{O}$. Cavities of clinoptilolite are filled with large ions that are capable of cation exchange without breaking the structure. High indexes of zeolite pozzolanic activity (by $\mathrm{CaO}$ absorption $-300 \mathrm{mg} / \mathrm{g}$ and by $\mathrm{CaSO}_{4}-147 \mathrm{mg} / \mathrm{g}$ ) provide the intensive binding of $\mathrm{Ca}(\mathrm{OH})_{2}$ in low hydrosilicates, hydrosulfoaluminates and calcium hydroaluminates [16].

Effects of Portland cement and zeolite tuff addition on the properties of composite gypsum binders were determined with the help of two-factor three-level mathematical experiment.

\section{Results and Discussion}

According to granulometric analysis (Table 2), gypsum binder is more coarsely dispersed than cement. For Portland cement CEM II/B-M 32.5 and masonry cement MC 22.5X the fractions content of Ø5; Ø10; Ø20; $\varnothing 60 \mu \mathrm{m}$ is $18.58 ; 31.62 ; 50.96 ; 85.56$ and $32.62 ; 46.43$; $62.30 ; 88.66 \%$, respectively. The grain size d10, d50, d90 corresponds to $2.13 ; 20.5 ; 69.7$ and $1.12 ; 11.19 ; 62.2 \mu \mathrm{m}$, respectively. For these cements, the ultrafine fraction $(\varnothing<1 \mu \mathrm{m})$ is $4.75-8.81 \%$, whereas it is absent in the gypsum. The maximum on the differential curve of particles distribution of zeolite and cement MC 22.5X corresponds to 3.95 and $3.59 \mu \mathrm{m}$, respectively.

Table 2

Particle size distribution for the gypsum binder, zeolite, CEM II/B-M and MC 22.5X

\begin{tabular}{|l|c|c|c|c|c|c|c|c|}
\hline \multicolumn{1}{|c|}{ Material } & $\begin{array}{c}\varnothing<1 \mu \mathrm{m}, \\
\%\end{array}$ & $\begin{array}{c}\varnothing<5 \mu \mathrm{m}, \\
\%\end{array}$ & $\begin{array}{c}\varnothing<10 \mu \mathrm{m}, \\
\%\end{array}$ & $\begin{array}{c}\varnothing<20 \mu \mathrm{m}, \\
\%\end{array}$ & $\begin{array}{c}\varnothing<60 \mu \mathrm{m}, \\
\%\end{array}$ & $\begin{array}{c}\mathrm{d} 10, \\
\mu \mathrm{m}\end{array}$ & $\begin{array}{c}\mathrm{d} 50, \\
\mu \mathrm{m}\end{array}$ & $\begin{array}{c}\mathrm{d} 90, \\
\mu \mathrm{m}\end{array}$ \\
\hline Gypsum binder & 0 & 9.45 & 23.79 & 46.75 & 80.75 & 4.76 & 23.3 & 84.3 \\
\hline Zeolite tuff & 3.44 & 23.47 & 38.75 & 58.76 & 87.92 & 1.93 & 15.6 & 66.6 \\
\hline CEM II/B-M & 4.75 & 18.58 & 31.62 & 50.96 & 85.56 & 2.13 & 20.5 & 69.7 \\
\hline MC 22.5X & 8.81 & 32.62 & 46.43 & 62.30 & 88.66 & 1.12 & 11.9 & 62.2 \\
\hline
\end{tabular}

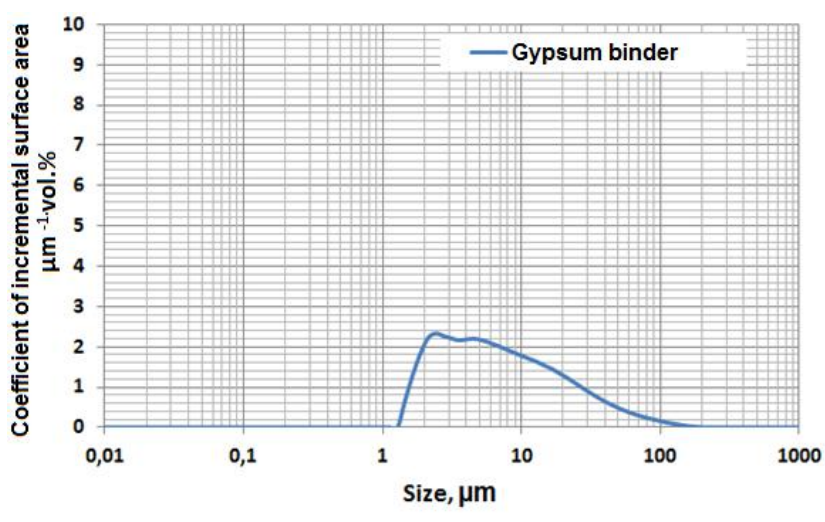

a)

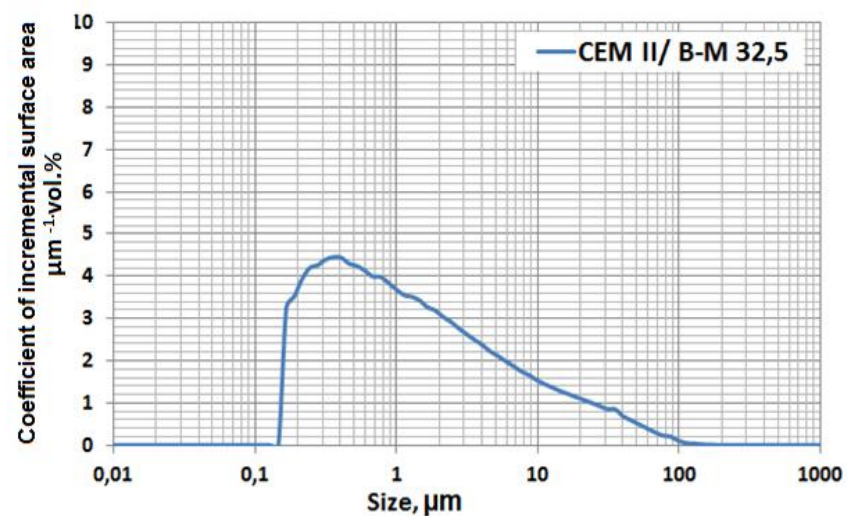

c)

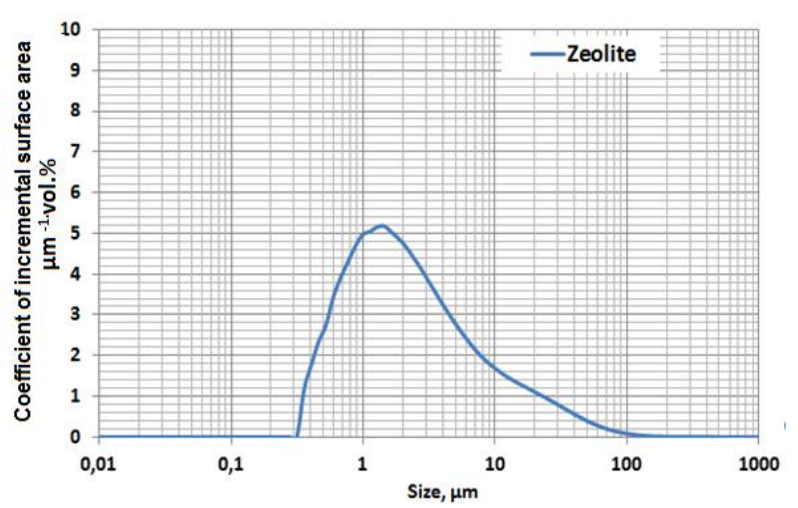

b)

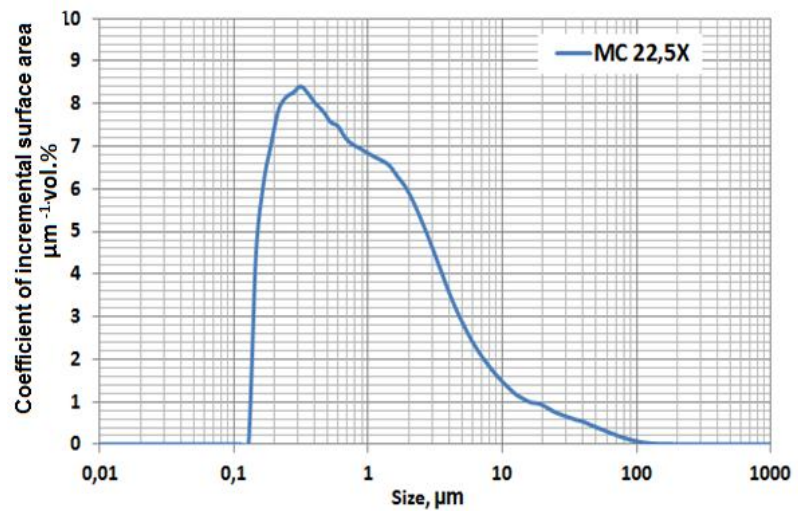

d)

Fig. 1. Coefficient of incremental surface area $\left(\mathrm{K}_{\text {isa }}\right)$ for gypsum (a); zeolite (b); Portland cement CEM II/B-M 32.5 (c) and masonry cement MS 22.5X (d) 
To determine the active surface of the mineral components phases, the coefficient of incremental surface area $\left(K_{i s a}\right)$ was calculated according to the methodology [17]. As can be seen from Fig. 1, for gypsum the maximum value of $K_{\text {isa }}$ is $2.2 \mu \mathrm{m}^{-1} \cdot \mathrm{vol} \%$. For the fraction $\varnothing=2.48 \mu \mathrm{m}$. For zeolite and Portland cement CEM II/BM 32.5 the coefficient increases to 5.17 and $4.45 \mu \mathrm{m}^{-1} \cdot \mathrm{vol} \%$ ( $\varnothing=1.62$ and $0.42 \mu \mathrm{m}$, respectively). The maximum value of $K_{i s a}$ is reached for cement MC 22.5X $\left(8.6 \mu \mathrm{m}^{-1} \cdot \mathrm{vol} \%\right.$ for $\left.\varnothing=0.314 \mu \mathrm{m}\right)$, while for the fractions greater than $10 \mu \mathrm{m}$, this coefficient is significantly lower and their contribution to the specific surface is less than $10 \%$, although the amount of the $10-100 \mu \mathrm{m}$ fraction particles is $76.31 \mathrm{vol} \%$. This indicates that ultrafine particles $(\varnothing<1 \mu \mathrm{m})$ of zeolite-containing cements, which are characterized by high surface energy, can have a significant effect on the structure formation and increase in strength of composite gypsum binders.

The quality of decorative composite gypsum binders is also determined by the degree of their whiteness. The increased level of whiteness (reflection coefficient) is typical for gypsum (85\%) and zeolite tuff $(70 \%)$, whereas the reflection coefficient of Portland cements CEM I, CEM II/A-P and CEM II/B-M ranges from 36 to $39 \%$. For masonry cement MC 22.5X, the reflection coefficient increases to $61 \%$ due to the increased content of zeolite and carbonate microfiller.

Table 3 shows that the zeolite-containing Portland cements CEM II/A-P 32.5 R, CEM II/B-M 32.5 R and masonry cement MC $22.5 \mathrm{X}$ are characterized by the reduction of clinker factor to $0.80-0.40$ due to the increase in mineral additives content in their composition from 20 to $60 \mathrm{wt} \%$. In this case, the $\mathrm{CO}_{2}$ emissions are reduced by 1.25-3.83 times, but the compressive strength of cements CEM II/A-P 32.5 R and CEM II/B-M 32.5 R (at 2 and 28 days - 22.4, 19.5 and $39.6,35.4 \mathrm{MPa}$, respectively) decreases only by $12-21 \%$ compared with Portland cement CEM I 42.5 R. The compressive strength of masonry cement, containing $60 \mathrm{wt} \%$ of additives and corresponding to MC $22.5 \mathrm{X}$ class, decreases by $48 \%$. The gypsum binder is characterized by a very low $(9.0 \mathrm{MPa})$ compressive strength; on the other hand, its carbon footprint factor $\left(140.7 \mathrm{kgCO}_{2} / \mathrm{t}\right)$ is lower by $4.0-6.1$ and 1.6 times compared to Portland cements and masonry cement respectively. This indicates the expediency of combining different types of binding substances to produce the low-carbon dioxide emission composites.

In order to determine the influence of Portland cement and mineral adjectives on the properties of gypsum cement-pozzolanic binders, experimental investigations were carried out in accordance with the plan of a two-factor three-level experiment. The amounts of CEM I $42.5\left(X_{1}=0 ; 10 ; 20 \mathrm{wt} \%\right)$ and zeolite $\left(X_{2}=0 ; 10\right.$;
$20 \mathrm{wt} \%$ ) were chosen as variables. Mathematical models describing the influence of Portland cement CEM I 42.5 and natural zeolite on the basic physico-technical properties of gypsum-cement-pozzolana binders are presented in the form of regression equations for compressive strength after $2 \mathrm{~h}\left(Y_{\mathrm{Rc} 2}\right)$ and 7 days $\left(Y_{\mathrm{Rc} 7}\right)$, and also for the porosity after $2 \mathrm{~h}\left(Y_{p}\right)$ and the softening coefficient $\left(Y_{K s}\right)$ :

$$
\begin{gathered}
Y_{\mathrm{Rc} 2}=6.26+0.02 X_{1}-0.57 X_{2}-0.91 X_{1}^{2}+0.11 X_{2}^{2}-0.44 X_{1} X_{2} ; \\
Y_{\mathrm{Rc} 7}=9.15+1.18 X_{1}+0.15 X_{2}-1.21 X_{1}^{2}-0.72 X_{2}^{2}+0.33 X_{1} X_{2} ; \\
Y_{p}=45.28-2.67 X_{1}+0.83 X_{2}+2.83 X_{1}^{2}+0.33 X_{2}^{2}-0.01 X_{1} X_{2} ; \\
Y_{K s}=0.58+0.08 X_{1}+0.04 X_{2}+0.03 X_{1}^{2}+0.03 X_{2}^{2}-0.01 X_{1} X_{2}
\end{gathered}
$$

Based on the graphical interpretation of mathematical models, the effective compositions of gypsum cement-pozzolane binders were obtained according to such criteria as strength, porosity and water resistance (Fig. 2). So, the maximum values of compressive strength and softening coefficient $\left(K_{s} \geq 0.6\right)$ are achieved for gypsum cement-zeolite binder with $20 \mathrm{wt} \%$ of Portland cement CEM I 42.5 and $10 \mathrm{wt} \%$ of natural zeolite.

Composite gypsum binders based on zeolitecontaining Portland cements CEM II/A-P 32.5, CEM II/B-M 32.5 and cement MC 22.5X have water demand of 52-56\% and standard strength of $6.4-7.3 \mathrm{MPa}$ (Fig. 3a). When $1.5 \mathrm{wt} \%$ of the polycarboxylate superplasticizer MasterGlenium ACE 430 is introduced into composite plaster binders with $25 \mathrm{wt} \%$ of zeolitecontaining cements, the water demand is reduced to 38 $42 \%$ with a simultaneous increase in the setting time by 8-10 min. At the same time, along with a decrease in water demand, there is a slowdown in the kinetics of early hardening for compositions with zeolite-containing cements. The compressive strength of the modified composite gypsum binder increases to $14.6-26.8 \mathrm{MPa}$ after 7, 28 and 90 days (Fig. 3b). Superplasticizer on the basis of polycarboxylate ether reduces porosity of a gypsum stone from 56 to $46 \%$, and for a stone on the basis of modified composite zeolite-containing plaster binder - from 53-50 to $43-41 \%$ (Fig. 4a). At the same time, the $K_{s}$ value of gypsum stone increases from 0.48 to 0.56 , whereas for the composite gypsum binder the more significant increase is observed (from $0.58-0.60$ to 0.72 0.76 ), which corresponds to the gypsum binder with a high water resistance (Fig. 4b). The strength of a composite binder based on $75 \mathrm{wt} \%$ G- $6+25 \mathrm{wt} \%$ MC22.5X in 28 days reaches $20 \mathrm{MPa}$ and in 2.3 times exceeds the strength of building plaster with the age of hardening as a result of pozzolanic reaction; the strength increases even more and the water resistance corresponds to the hydraulically hardened binders. The carbon footprint $\left(163.0 \mathrm{~kg} \mathrm{CO}_{2} / \mathrm{t}\right)$ of this composite binder is only by $15.8 \%$ higher than that for building plaster. 
Table 3

Physical and mechanical properties of binders

\begin{tabular}{|c|c|c|c|c|c|c|c|}
\hline \multirow[t]{2}{*}{ Binder } & \multirow{2}{*}{$\begin{array}{c}S S A \\
\mathrm{~m}^{2} / \mathrm{kg}\end{array}$} & \multirow{2}{*}{$\begin{array}{c}\text { Water } \\
\text { demand, \% }\end{array}$} & \multicolumn{2}{|c|}{ Setting time, min } & \multicolumn{2}{|c|}{$\begin{array}{l}\text { Compressive strength, } \\
\mathrm{MPa} / \% \text {, at age }\end{array}$} & \multirow{2}{*}{$\begin{array}{c}\text { Emission of } \\
\mathrm{CO}_{2}, \\
\mathrm{~kg} / \mathrm{t} \text { binder }\end{array}$} \\
\hline & & & initial & final & 2 days & 28 days & \\
\hline CEM I $42.5 \mathrm{R}$ & 375 & 29.2 & 170 & 230 & $28.0 / 100$ & $44.8 / 100$ & 864.5 \\
\hline CEM II/A-P 32.5R & 410 & 30.5 & 150 & 210 & $22.4 / 80.0$ & $39.6 / 88.4$ & 691.6 \\
\hline CEM II/B-M 32.5 R & 390 & 28.9 & 170 & 220 & $19.5 / 69.6$ & $35.4 / 79.0$ & 564.2 \\
\hline MC 22.5X & 700 & 31.0 & 180 & 240 & $8.7 / 31.1$ & $23.2 / 51.8$ & 225.8 \\
\hline Gypsum binder & 480 & 61,0 & 10 & 18 & $6.3 / 22.5$ & $9.0 / 20.1$ & 140.7 \\
\hline
\end{tabular}

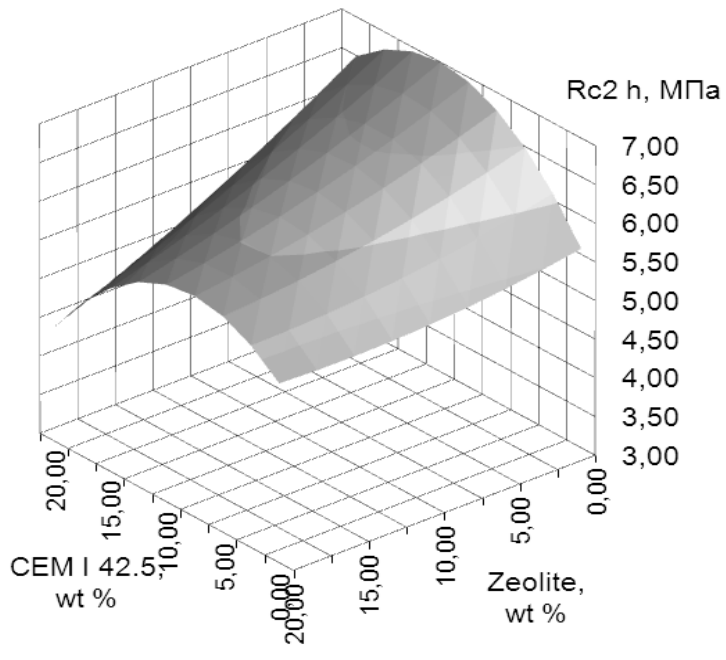

a)

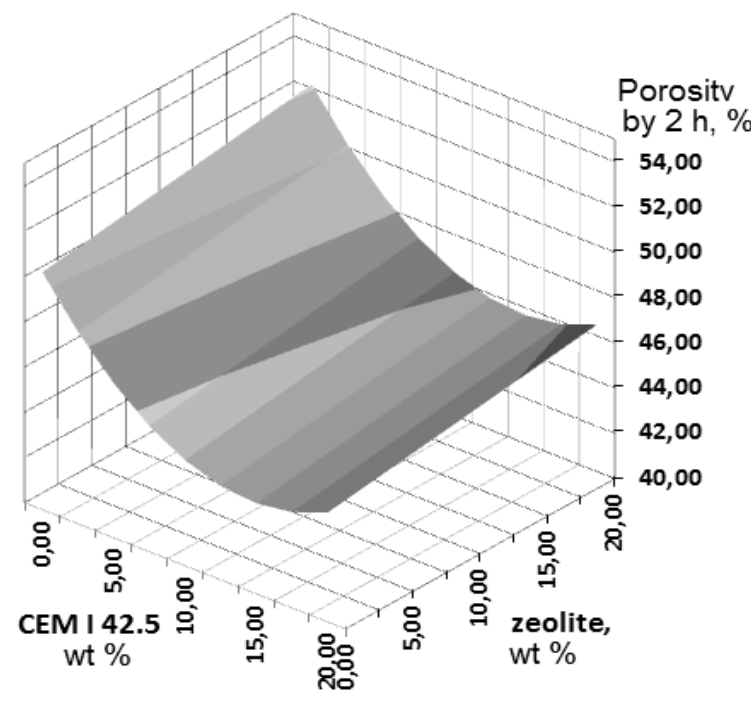

c)

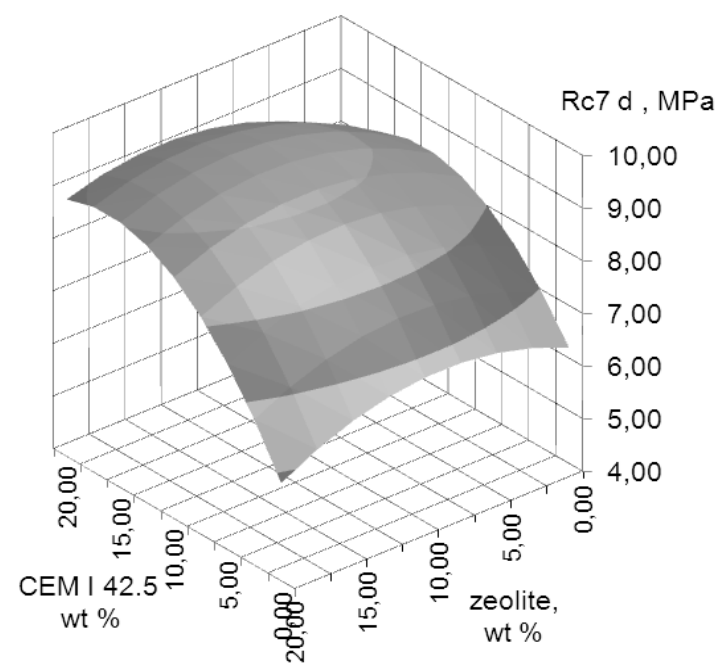

b)

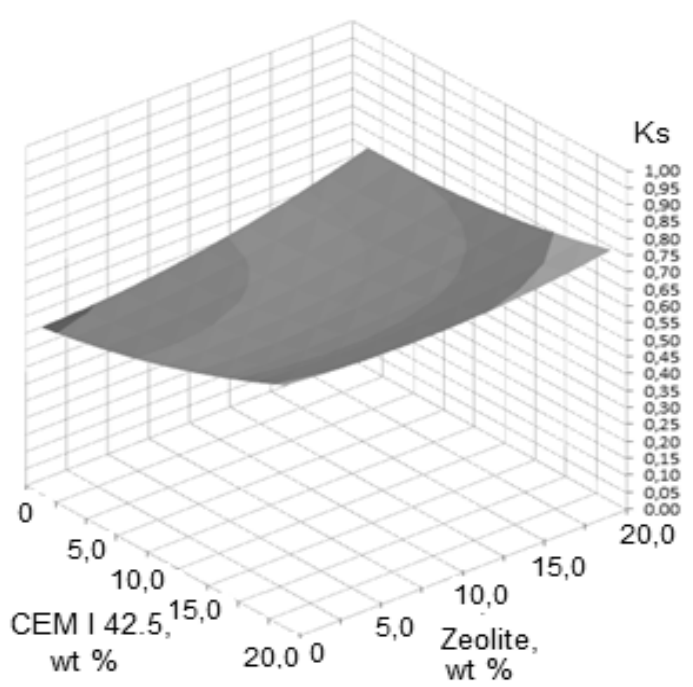

d)

Fig. 2. Isoparametric diagrams of change in strength after $2 \mathrm{~h}$ (a) and 7 days (b) of hardening, porosity (c) and softening coefficient $(\mathrm{d})$ of composite binders 




a)

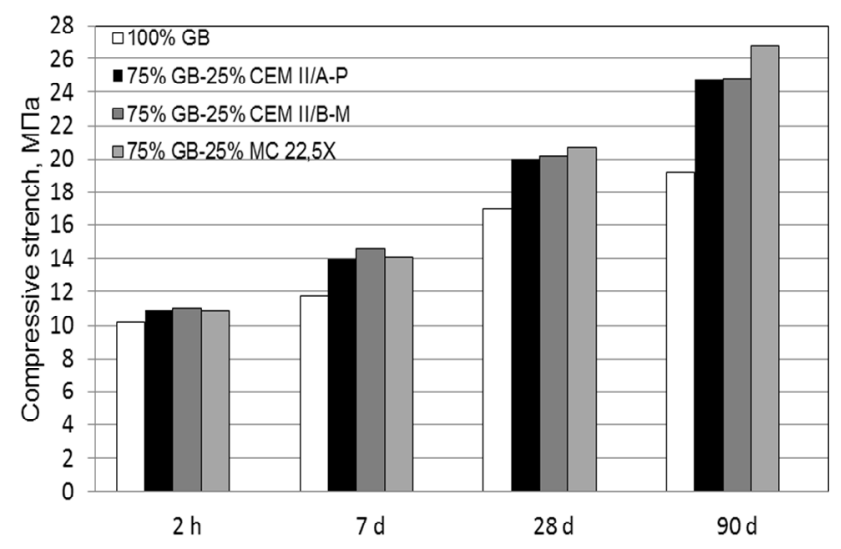

b)

Fig. 3. Compressive strength of composite gypsum binders without additives (a) and with PCE (b)

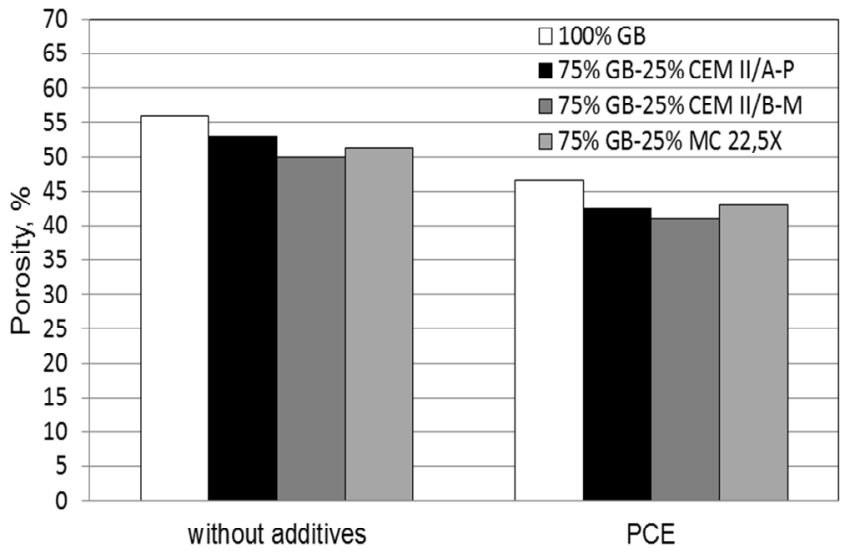

a)

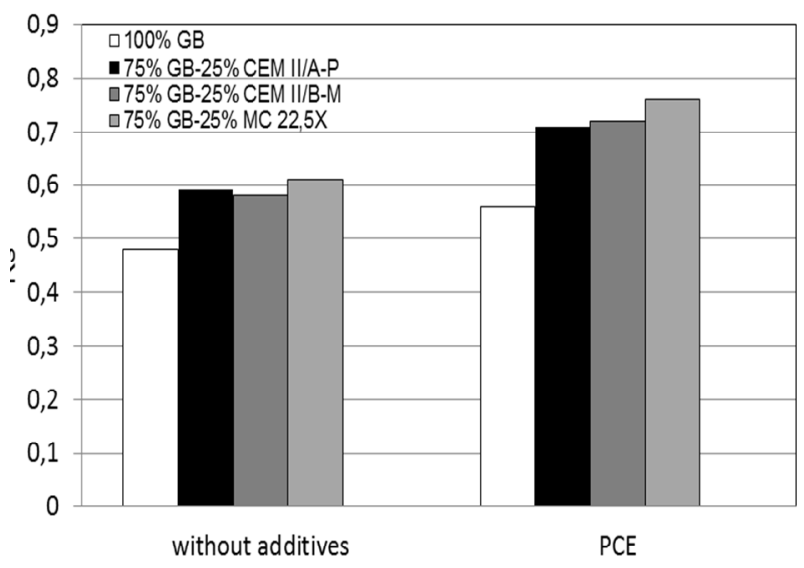

b)

Fig. 4. Porosity (a) and softening coefficient (b) of composite gypsum binders

XRD analysis showed that the main lines of the hemihydrate plaster $\mathrm{CaSO}_{4} \cdot 0.5 \mathrm{H}_{2} \mathrm{O}(d / n=0.349 ; 0.269$; $0.213 \mathrm{~nm}$ ), as well as the insignificant amount of dihydrate $\mathrm{CaSO}_{4} \cdot 2 \mathrm{H}_{2} \mathrm{O}(d / n=0.756,0.427,0.379,0.306,0.286$, $0.249 \mathrm{~nm}$ ) were observed on the diffractogram of the gypsum binder. When the gypsum binder with the addition of Portland cement CEM I 42.5 is hardening in air-dry conditions (90 days), apart from intense lines of dihydrate, an intensive line of calcium hydroxide $(d / n=0.493 \mathrm{~nm})$ and low-intensive lines of ettringite $(0.973 ; 0.561 \mathrm{~nm})$ were found. When introducing composite cements CEM II/B-M and $\mathrm{MC} 22.5 \mathrm{X}$, the lines of ettringite decrease by $1.5-2.0$ times, and the lines of calcium hydrocarboaluminates $(d / n=0.76 ; 0.38 \mathrm{~nm})$ appear; at the same time the lines of calcium hydroxide are absent.

The microstructure of hydrated gypsum is a frame consisting of elongated columnar small crystals of calcium sulfate dihydrate of $4-10 \mu \mathrm{m}$ in size. These crystals are interconnected into a single solid, permeated with capillary pores of width $15-30 \mu \mathrm{m}$ and air pores of $50-100 \mu \mathrm{m}$. So, total porosity is $56 \%$, and capillary porosity $-39 \%$. Due to the high porosity of the stone, its strength is low. The microstructure of gypsum stone with polycarboxylate superplasticizer is denser due to the decrease in water demand and the dihydrate crystals are also formed in the form of plates. Total porosity decreases to $46 \%$, including the open porosity of $27 \%$, and the closed one increases to $19 \%$.

Calcium sulfate dihydrate crystals in the form of staggered and lamellar forms, as well as needle crystals of ettringite are observed in a CGB-based stone ( $75 \mathrm{wt} \%$ of gypsum binder - $25 \mathrm{wt} \%$ of MC 22.5X) (Fig. 5). If this paste is modified with PCE, there are changes in size and shape of calcium sulfate dihydrate crystals (Fig. 6). Moreover, the microstructure of such a paste is characterized by the presence of crystal lamellar forms, which are cemented with submicroscopic formations of Portland cement hydration products. For the modified stone microstructure, a partial monolithing of multicomponent cement MC $22.5 \mathrm{X}$ by the products of hydration is characteristic. The stone is packed and the number of pores decreases to $41 \%$, including the open pores ( $23 \%)$. 




a)

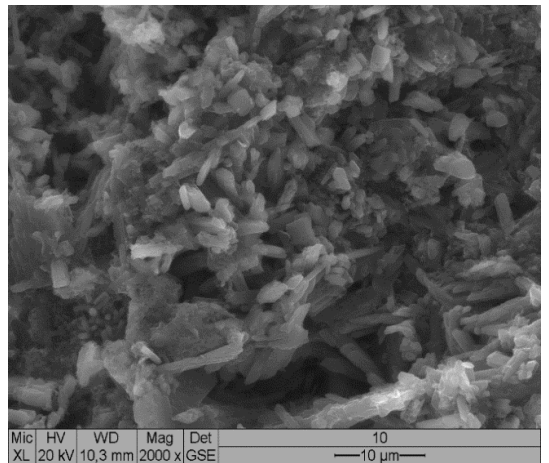

b)

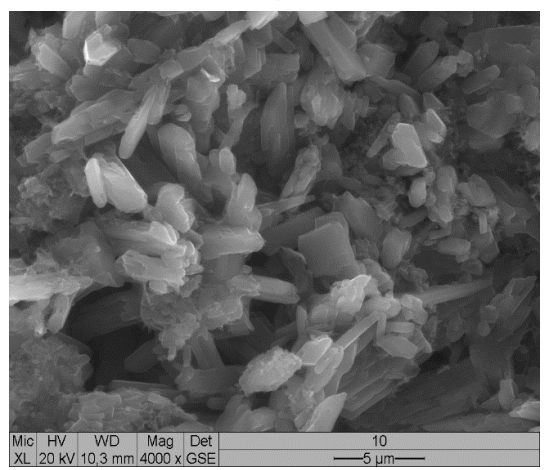

c)

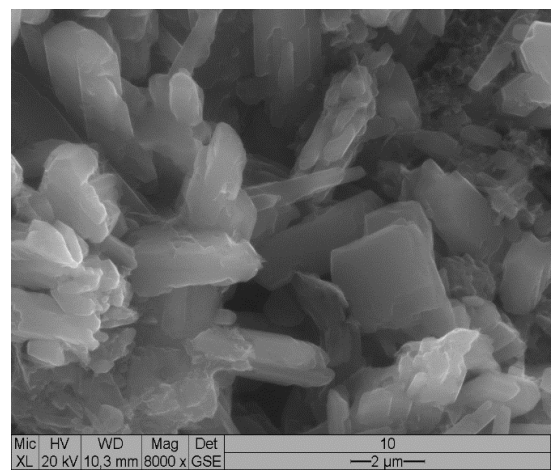

d)

Fig. 5. Microstructure of CGB-based stone with the addition of masonry cement MS 22.5X after 90 days

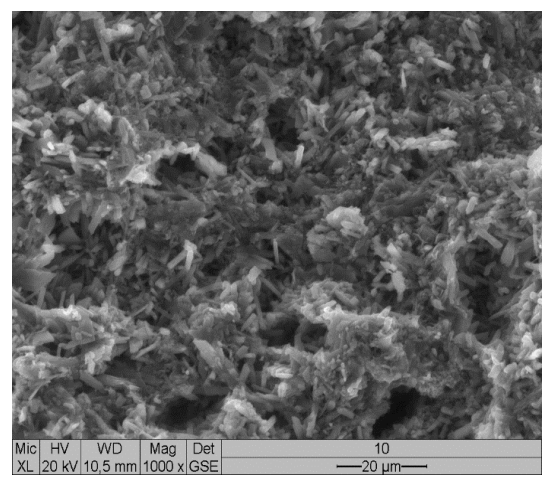

a)



b)

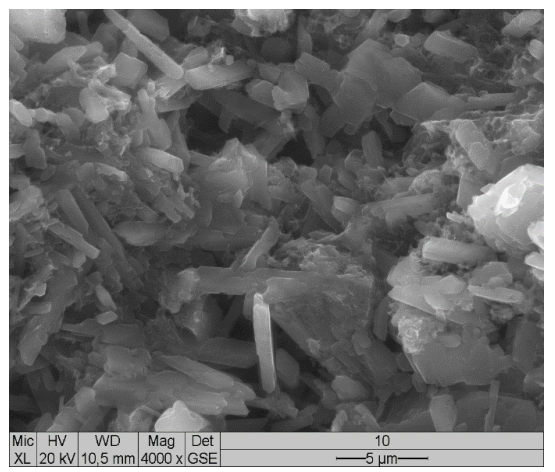

c)

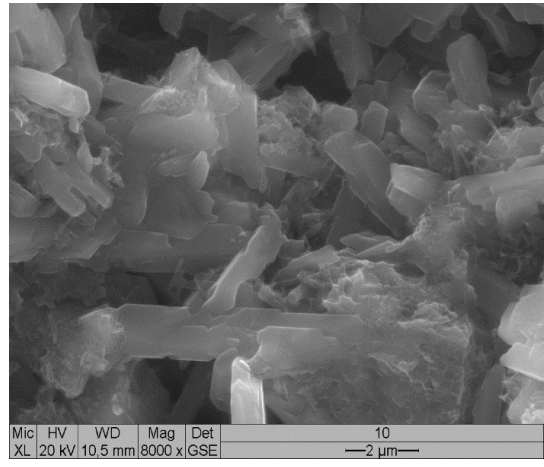

d)

Fig. 6. Microstructure of CGB-based stone with the addition of PCE-modified masonry cement MS 22.5X after 90 days 
Hence, the result of the composite gypsum binder modification by PCE type polycarboxylate superplasticizer is a convergence of the dispersed phase particles at a rather small distance in the initial period of structuring, when crystallization contacts with an enlarged total area are formed. Calcium hydroxide, which is released during the hydration of Portland cement alite phase, increases $\mathrm{pH}$ of the liquid phase. Under alkaline conditions the crystals of calcium sulfate dihydrate are obtained in the form of a lamellar form due to the adsorption modification. As the calcium hydroxide is bound by the ultrafine part of the zeolite, nano-dispersed CSH-phases and larger crystals of hexagonal plate-like $\mathrm{AF}_{\mathrm{m}}$-phases are formed, while the amount of ettringite decreases. The presence of such hydrated formations, which harden large dihydrate crystals formed at the first stage of hardening, determines the increased strength and water resistance of the stone.

The modified composite zeolite-based plaster binders with the high water resistance can be used for the production of building mortars and concrete, dry mixtures for plaster, finishing and restoration works, as well as partitions and walls in wet rooms, for the formation of bulky elements of sanitary cabinets, in production of plates and panels for floors, devices of self-leveling screeds under a floor. Such modified composite binders based on gypsum binder and multimodal cements with an optimized particle distribution due to the introduction of highly dispersed zeolite-containing mineral additives and carbonate microfillers can significantly reduce the power consumption of construction products and $\mathrm{CO}_{2}$ emissions, which is consistent with the strategy of sustainable development in the construction.

\section{Conclusions}

The complex combination of gypsum, Portland cement clinker, pozzolan zeolite-containing components, as well as the use of superplasticizers on the basis of polycarboxylates allows to produce environmentally friendly modified composite gypsum binders with the increased water resistance. Based on the results of granulometric analysis it has been shown that ultrafine particles of zeolite and limestone with high values of "excess surface energy", being a part of composite cements, directly influence the increase in strength and water resistance of the modified composite gypsum cement-zeolite binders. The multicomponent gypsum binders with the preservation of the positive properties of gypsum products and the acquisition of hydraulic properties of Portland cement were created. It has been shown that the appearance of a significant amount of waterproof hydrate formations promotes the development of hydraulic properties, the increase in strength, water resistance and durability of composite gypsum products as a whole.

\section{References}

[1] Pervyshin G., Yakovlev G., Gordina A. et al.: Procedia Eng., 2017, 172, 867. https://doi.org/10.1016/j.proeng.2017.02.087

[2] Plugin O., Plugin A., Plugin D. et al.: MATEC Web of Conferences, 2017, 116, 01013. https://doi.org/10.1051/matecconf/201711601013

[3] Vimmrová A., Keppert M., Michalko O., Černý R.: Cement Concrete Comp., 2014, 52, 91 .

https://doi.org/10.1016/j.cemconcomp.2014.05.011

[4] Zinin E., Sycheva L.: Uspekhi Khimii i Khim. Technol., 2017, XXXI, 37.

[5] Lushnikova N., Dvorkin L.: Sustainability of gypsum products as a construction material [in:] Khatib J. (Ed.), Sustainability of Construction Materials ( $2^{\text {nd }}$ edn.). Woodhead Publ. 2016, 643-681.

https://doi.org/10.1016/B978-0-08-100370-1.00025-1

[6] Sanytsky M., Fischer H.-B., Soltysik R., Korolko S.: $15^{\text {th }}$ Ibausil, Internationale Baustofftagung, Weimar, Germany 2003, 0211.

[7] Kondratieva N., Barre M., Goutenoire F., Sanytsky M.: Construct. Build. Mater., 2017, 149, 535.

https://doi.org/10.1016/j.conbuildmat.2017.05.140

[8] Potapova L., Kais H., Galiev T.: Innovatsionnaya Nauka, 2016, 6, 134.

[9] Korovyakov V.: Cement, Beton, Sukhie Smesi, 2009, 6, 92.

[10] Rakhimov R., Guyfullin A., Khaliullin M.: Bull. Kazan Technol. Univ., 2013, 7, 129.

[11] Sikora P., Elrahman M., Stephan D.: Nanomater., 2018, 8, 465. https://doi.org/10.3390/nano8070465

[12] Sanytsky M., Kropyvnytska T., Kotiv R.: Adv. Mater. Res., 2014, 923, 42. https://doi.org/10.4028/www.scientific.net/AMR.923.42 [13] Sobol K., Blikharskyy Z., Petrovska N. et al.: Chem. Chem. Technol., 2014, 8, 461. https://doi.org/10.23939/chcht08.04.461

[14] Rudenko I. et al.: Key Eng. Mater., 2018, 761, 27.

https://doi.org/10.4028/www.scientific.net/KEM.761.27

[15] Kropyvnytska T., Semeniv R., Ivashchyshyn H.: MATEC Web of Conferences, 2017, 116, 01007.

https://doi.org/10.1051/matecconf/201711601007

[16] Sanytsky M., Sobol Kh., Shcturmay M., Khymko O.: Chem. Chem. Technol., 2011, 5, 227.

[17] Sanytsky M., Kropyvnytska T., Kruts T. et al.: Key Eng. Mater., 2018, 761, 193.

https://doi.org/10.4028/www.scientific.net/KEM.761.193

Received: November 01, 2018 / Revised: December 01, 2018 / Accepted: February 12, 2019

\section{ЕФЕКТИВНІСТЬ НИЗЬКОКАРБОНОВИХ КОМПОЗИТНИХ ГІПСОВИХ В'ЯЖУЧИХ З ПІДВИЩЕНОЮ ВОДОСТІЙКІСТЮ}

Анотація. Приведено екологічні переваги використання низькокарбонових композитних гіпсових в'яжучих з підвищеною водостійкістю в будівниитві. Досліджено вплив ультрадисперсних частинок цеоліту на фізико-механічні властивості та прочеси гідратації композитних гіпсових в яжучих. Модифікація гіпсових паст суперпластифікатором полікарбоксилатного типу призводить до радикальних змін у формуванні мікроструктури композитних гіпсових в'яжучих речовин. Показано, що отримані результати є важсливими для подальшого проектування та розроблення нових типів гіпсових композитів з підвищеною водостійкістю.

Ключові слова: низькокарбонові композитні гіпсові в 'яжучі, багатокомпонентні цементи, природний цеоліт, полікарбоксилатний суперпластифікатор, міџність на стиснення, водостійкість. 